\title{
Preceding crops and residue management practices on performance of mustard under zero-till semi-arid condition
}

\author{
LP Amgain ${ }^{1}$ and AR Sharma ${ }^{2}$ \\ ${ }^{1}$ Institute of Agriculture and Animal Sciences, Rampur, Chitwan, Nepal \\ ${ }^{2}$ Directorate of Weed Science Research, Jabalpur, India
}

\begin{abstract}
A field experiment was conducted in 2010/11 and 2011/12 at New Delhi to study the performance of zero-till rainfed mustard. The influence of preceding rainy season crops, viz. pearl millet, cluster bean and green gram; and residue management, viz. no residue, crop residue and Leucaena twigs mulching on this mustard crop was observed. Pooled analysis of mustard seed yield was significantly higher $(+51 \%)$ in 2010/11 $(1.80 \mathrm{t} / \mathrm{ha})$ than 2011/12 (1.19 t/ha) due to favourable weather condition in the first year. Further, Leucaena twigs mulching resulted higher seed yield of $2.17 \mathrm{t} / \mathrm{ha}$ in $2010 / 11$ than $1.94 \mathrm{t} / \mathrm{ha}$ in $2011 / 12$. Green gram as preceding crop resulted significantly higher mustard yield in 2010/11, while it was higher after cluster bean in 2011/12. Interaction between crop residue and preceding rainy season crops on growth parameters exerted significant variations, while yield attributes showed the mixed response. Cluster bean with Leucaena twigs led to higher yield of mustard, followed by green gram with crop residue. Economic analysis exhibited the highest net return of mustard grown after cluster bean with Leucaena twigs mulching. From the findings it is observed that growth indices, yield, and yield attributes and economics of mustard were influenced significantly by preceding crops and crop residue application. The effect of Leucaena twigs was found better in 2010/11, while both crop residues and Leucaena twigs mulching were equally effective in 2011/12. Cluster bean as preceding crop to mustard resulted higher yield and net returns, followed by green gram and cluster bean with crop residues. It was suggested that mustard after cluster bean with Leucaena twigs was a high yielding and profitable cropping system under zero-till semi-arid condition. It was concluded that growing mustard after cluster bean with Leucaena twigs mulching resulted increased yield and profitable cropping system for rainfed areas in zero-till semi arid condition of New Delhi.
\end{abstract}

Key words : economics, preceding crops, rainfed mustard, residue management, zero-till

\section{Introduction}

Fallowing or cultivation of short duration crops like pearl millet [Pennisetum glaucum (L.) $\mathrm{R} \mathrm{Br}$ Emend Stuntz], cluster bean [Cyamopsis tetragonoloba (L.) Taub.], and green gram (Vigna radiata L.) during rainy season followed by a long duration drought hardy crop like mustard (Brassica juncea L. Czern. \& Coss.) during winter season on the conserved soil moisture is commonly followed in semi-arid areas of India and Pakistan (Faroda et al., 2007; Singh et al., 2008). These crops are mostly grown in ploughed land, which not only deteriorates the soil environment, but also increases the cost of production. Conservation tillage (zero-tillage + residue mulching + crop diversification) is a useful practice in rainfed areas to control soil erosion and weed growth as well as to preserve soil moisture and plant nutrients in the soil profile (Narain and Singh, 1997; Sharma et al., 2005a). Inclusion of legumes in the crop rotation further plays a vital role in improving 
balanced plant nutrition (Saxena, 2012) and building up of soil fertility through the addition of biologically fixed nitrogen (Ali et al., 2002).

There are several evidences of remarkable increase in the yield of crops in the rainfed cropping system through the maintenance of appropriate vegetative cover under no-till condition (Dhyani et al., 2009). Mulching of crop field by Leucaena leucocephala helps in conserving soil moisture for proper growth and development of crops (Sharma et al., 2010). The use of vegetative cover under zero-tillage condition helps to increase root growth by creating favourable soil environment and decreasing weed infestation. This situation is ideal for better plant growth and higher yield of winter crops (Singh et al., 1998). In-situ application of the residue of pearl millet, cluster bean and green gram in winter season crops, and the residue of mustard in rainy season crops is practiced because of the easy access to residual material through seasonal harvest. In zero-till condition, the introduction of happy seeder (a machine) makes it easy to sow seeds of any crop, like mustard in standing residue (Jat et al., 2009). This discussion suggests that the adoption of resource conserving technologies, such as zero-tillage and residue management is essential in rainfed condition to improve productivity, resource-use efficiency and sustainability of low input agriculture. Therefore, the aim in this research is to understand the effects of preceding crops and residue management in mustard under zero-till semi-arid condition.

\section{Materials and methods}

A field experiment was conducted in 2010/11 and 2011/12 at the Indian Agricultural Research Institute, New Delhi $\left(28^{\circ} 40^{\prime} \mathrm{N}, 77^{\circ} 12^{\prime} \mathrm{E}\right)$ at an altitude of $228 \mathrm{~m}$ above the mean sea level in sandy-loam soil to study the effects of preceding rainy season crops and residue management on growth, productivity, nutrient uptake, and economics of mustard-based cropping system. The soil of the research site contains $147.2 \mathrm{~kg} / \mathrm{ha}$ alkaline $\mathrm{KMnO}_{4}$-oxidizable $\mathrm{N}, 17.0 \mathrm{~kg} / \mathrm{ha} \mathrm{NaHCO}_{3}-$ extractable $\mathrm{P}, 225.1 \mathrm{~kg} / \mathrm{ha} 1 \mathrm{~N} \mathrm{NH}_{4} \mathrm{OAc}$-exchangeable $\mathrm{K}, 0.40 \%$ organic $\mathrm{C}$ with $7.5 \mathrm{pH}$ (1.2.5 soil and water ratio). The area received $954 \mathrm{~mm}$ rainfall in 2010/11. In 2011/12, the occurrence of rainfall in the same area was $662 \mathrm{~mm}$, which was 30.6\% less than that of 2010/11 and 10.4\% less than the average of the previous 10 years $(739 \mathrm{~mm})$. The number of rainy days and the volume of rainfall both were higher during the mustard growing season (October to March) in 2010/11 than in 2011/12. In 2010/11, the number of rainy days during the mustard growing season was 10 and the volume of rainfall was $85 \mathrm{~mm}$, but in 2011/12 the number of rainy days was two and the volume of rainfall was $14 \mathrm{~mm}$. Mustard crop sown on $3^{\text {rd }}$ October 2011 did not germinate for 25 days and to ensure the germination, irrigation measuring $20 \mathrm{~mm}$ was given on crop rows. Three cropping systems with combinations of three crops each (pearl millet, cluster bean and green gram) were grown in sequence in rainy season before mustard, exclusively under zero-till rainfed condition following other recommended package of practices with three treatments of surface cover management, viz. control (no residue), crop residues@5 t/ha and Leucaena twigs@10 t/ha.

The experiment was laid out in Randomized Block Design with four replications. Mustard cv. 'Pusa Vijaya' was sown on 18 October 2010, and 3 October 2011 at $40 \mathrm{~cm}$ row spacing by using happy seeder. The crop was fertilized with $60.40 .20 \mathrm{~kg}$ NPK per hectare. The full dose of P and K along with half $\mathrm{N}$ was applied through DAP, MOP and urea in the basal application. Diammonium phosphate was mixed with seeds of mustard and placed together in seed box of happy seeder for its proper distribution. However, muriate of potash and urea were broadcasted in the field. Crops were matured from the second to third week of March in both years. 
Growth indices, like crop growth rate (CGR), relative growth rate (RGR), and net assimilation rate (NAR) were calculated from 30 DAS to harvest. The yield attributes like plant population per square metre was counted at maturity from the fixed one metre row inserted with pegs from the beginning, while primary branches per plant and siliquae per plant were counted from randomly selected five plants. Number of seeds per siliqua and 1000 seed weight were taken from randomly selected 20 siliquae. The seed and stover yields, and harvest index were recorded from a plot of 10 $\mathrm{m}^{2}$ area. The recorded seed yield was adjusted at $10 \%$ for moisture. Pooled analysis of seed yield was carried out for evaluation of year effect. Economic analysis was undertaken to find out the cost of cultivation, gross and net returns, and net returns on investment. The biometric data on ancillary and yield parameters were analyzed by using standard statistical techniques. The regression analysis of major yield attributes and seed yield was also done.

\section{Results and discussion}

\section{Soil moisture availability and growth indices of mustard}

The calculated data showed that the values of CGR, RGR, and NAR between 30-60 DAS and 60-90 DAS were higher under the Leucaena twigs than the crop residue after cluster bean and green gram as preceding crops (Table 1 and Table 2). A comparatively higher CGR was recorded between 0 to 30 DAS in 2010/11. This might be due to 22 and $10 \mathrm{~mm}$ of rain received within two to three weeks of sowing. The soil moisture condition was different to produce different result in 2011/12. The initial soil moisture content was very low due to high evaporation rate coinciding with high ambient temperature during October 2011. Due to this reason, shallow irrigation in crop rows could not improve the growth of the crop. The moisture availability was directly influencing the CGR, RGR and NAR at different stages of mustard in 2010/11 and 2011/12 (Figure 1).

Table 1. Effect of crop residue and Leucaena twigs on crop growth indices of mustard after rainy season crops in 2010/11

\begin{tabular}{|c|c|c|c|c|c|c|c|c|c|}
\hline \multirow[t]{4}{*}{ Treatment } & \multicolumn{4}{|c|}{ CGR $\left(\mathrm{g} / \mathrm{day} / \mathrm{m}^{2}\right)$} & \multicolumn{3}{|c|}{ RGR (g/g/day) } & \multicolumn{2}{|c|}{ NAR $\left(\mathrm{g} /\right.$ day $\left./ \mathrm{m}^{2}\right)$} \\
\hline & $0-30$ & $30-60$ & $60-90$ & $90-120$ & $30-60$ & $60-$ & $90-$ & $30-60$ & $60-90$ \\
\hline & DAS & DAS & DAS & DAS & DAS & 90 & 120 & DAS & DAS \\
\hline & & & & & & DAS & DAS & & \\
\hline PM- NR & 1.68 & 2.11 & 3.05 & 2.76 & 0.060 & 0.065 & 0.064 & 0.526 & 0.318 \\
\hline PM - CR & 2.24 & 4.14 & 4.61 & 3.03 & 0.070 & 0.071 & 0.065 & 0.523 & 0.332 \\
\hline PM - LT & 5.14 & 4.38 & 4.00 & 3.99 & 0.071 & 0.069 & 0.069 & 0.440 & 0.360 \\
\hline CB - NR & 2.75 & 2.81 & 6.72 & 1.14 & 0.064 & 0.077 & 0.051 & 1.262 & 0.200 \\
\hline $\mathrm{CB}-\mathrm{CR}$ & 4.02 & 3.75 & 8.45 & 1.99 & 0.068 & 0.080 & 0.059 & 0.930 & 0.170 \\
\hline $\mathrm{CB}-\mathrm{LT}$ & 5.67 & 4.58 & 11.04 & 2.65 & 0.071 & 0.084 & 0.063 & 0.392 & 0.150 \\
\hline GG - NR & 3.31 & 1.59 & 5.06 & 3.30 & 0.056 & 0.073 & 0.067 & 1.251 & 0.222 \\
\hline GG - CR & 3.23 & 3.92 & 7.51 & 7.08 & 0.069 & 0.078 & 0.078 & 0.753 & 0.182 \\
\hline GG - LT & 5.40 & 2.03 & 8.08 & 5.86 & 0.059 & 0.079 & 0.075 & 0.625 & 0.180 \\
\hline
\end{tabular}


Table 2. Effect of crop residue and Leucaena twigs on crop growth indices of mustard after rainy season crops in 2011/12

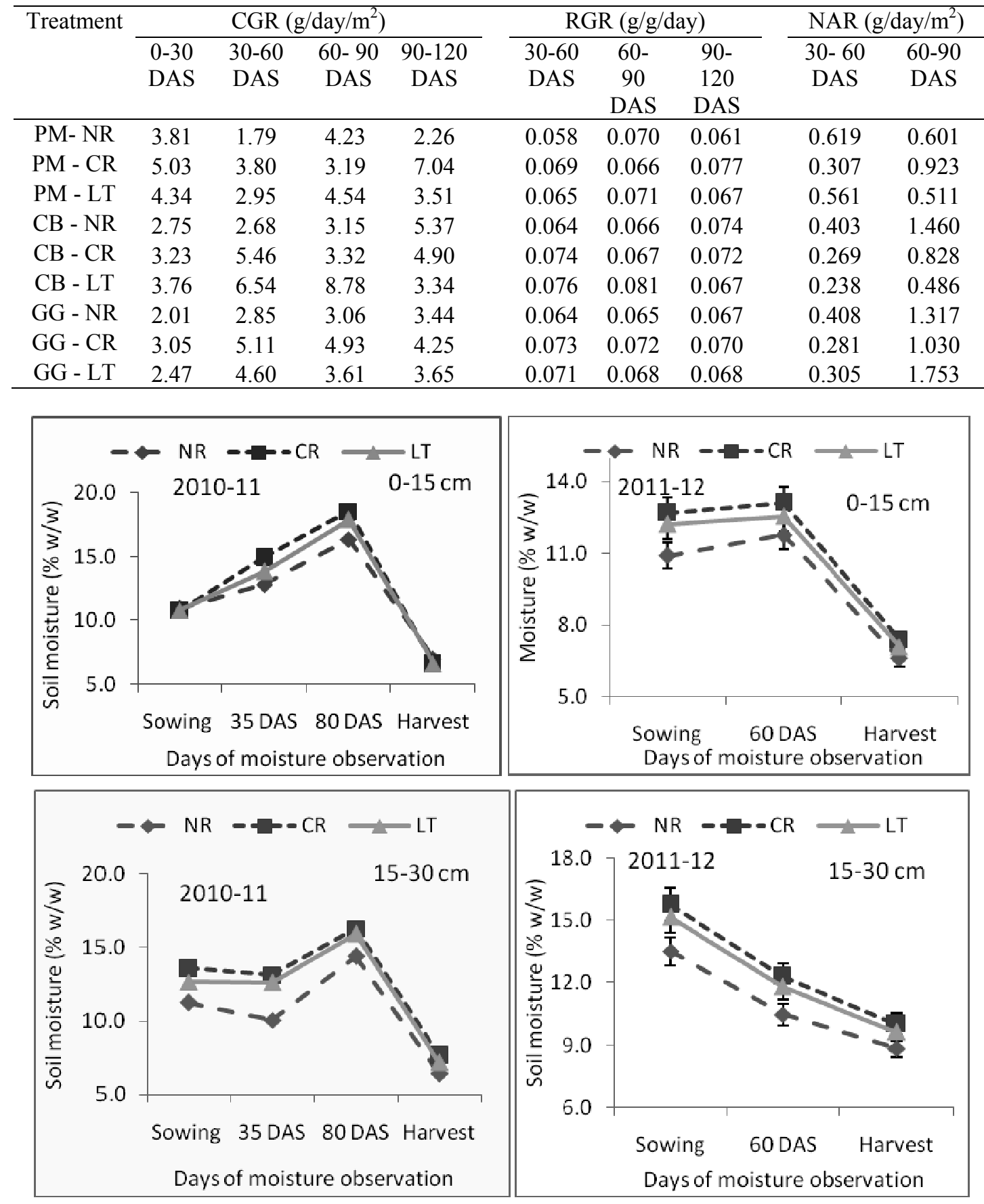



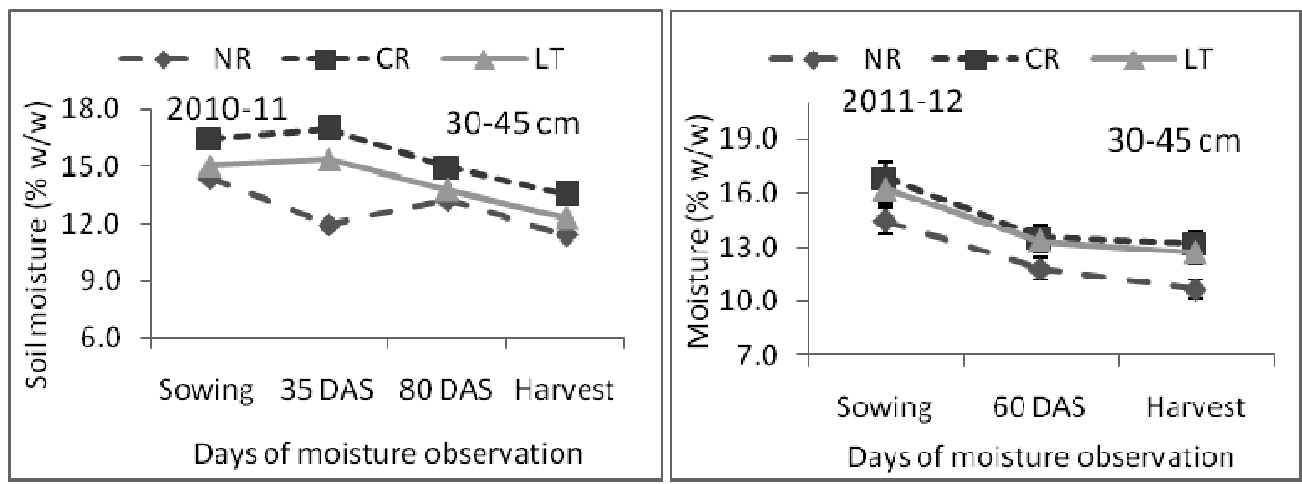

Figure 1. Soil moisture profile (w/w \%) in mustard field as influenced by residue retention practices in 2010/11 and 2011/12

Mustard is a drought hardy crop. This crop can grow and give some yield in rainfed area by utilizing the conserved soil moisture. Leucaena twigs and crop residue mulching plots recorded more soil moisture conservation than no residue and helped to augment crop growth. Mustard being grown as rainfed, followed no definite trend in growth indices due to variable availability of soil moisture through rainfall. Forty nine mm of rainfall received in February 2011 and $14 \mathrm{~mm}$ of rainfall received in January 2012 helped to augment the CGR in later stages of the crop as it was rejuvenated after getting soil moisture. Crop residue of most crops and Leucaena twigs in cluster bean provided relatively higher CGR, RGR and NAR than without residue and after green gram and cluster bean as preceding crops. This indicated that soil environment could be made favourable through the application of crop residue and growing legumes as preceding crops in mustard based system. Several researchers (Rathore et al., 1998; Singh et al., 2003; Rathore et al., 2008) reported higher crop growth rate and RGR of mustard when it is followed by legumes and mulched with crop residue.

\section{Yield and yield attributes of mustard}

Yield of mustard, and their correlation and regression with major yield attributes as affected by preceding rainy season crops and residue management practices are presented in Figure 2 and 3. Except plant population per square metre at maturity in 2010/11, the effect of preceding crops on most of the yield attributes, seeds per siliqua in 2011/12, and 1000 seed weight in both years showed significant variation. Legumes improve soil fertility and conserve soil moisture, which led to more yield than pearl millet as preceding crop. All major yield attributes, such as plant population per square metre at maturity, primary branches per plant, siliquae per plant and 1000 seed weight were found to be significantly higher in the plots where residue management was done properly. Cluster bean as previous crop with Leucaena twigs as mulch, and green gram and pearl millet as previous crops with crop residue as mulch resulted significantly high plant population per square metre at maturity and 1000 seed weight in 2011/12, and siliquae per plant in both years. Higher yield attributes were observed from the crop mulched with Leucaena twigs and crop 

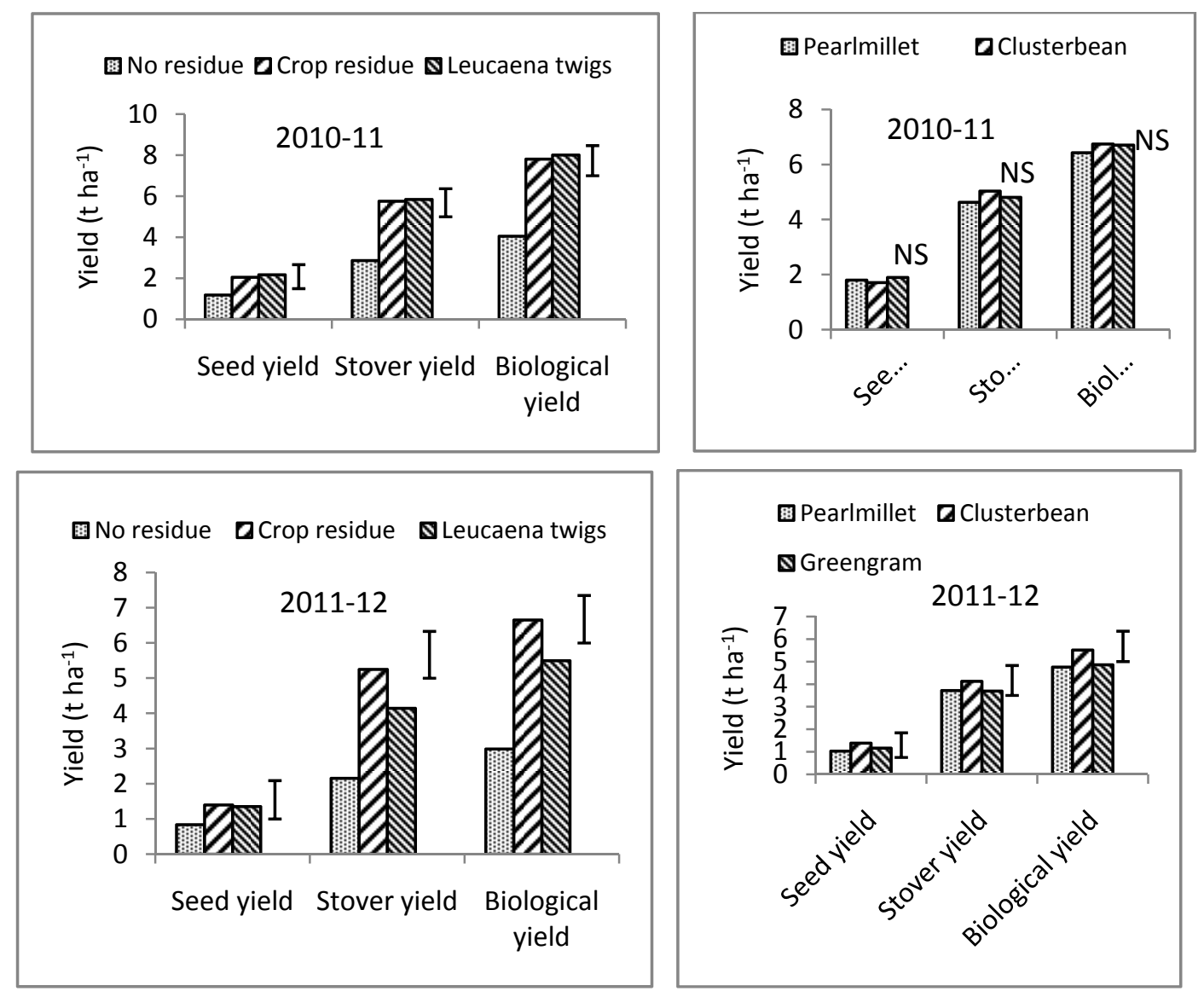

Figure 2. Yield performance of mustard as influenced by residue management and preceding rainy season crops
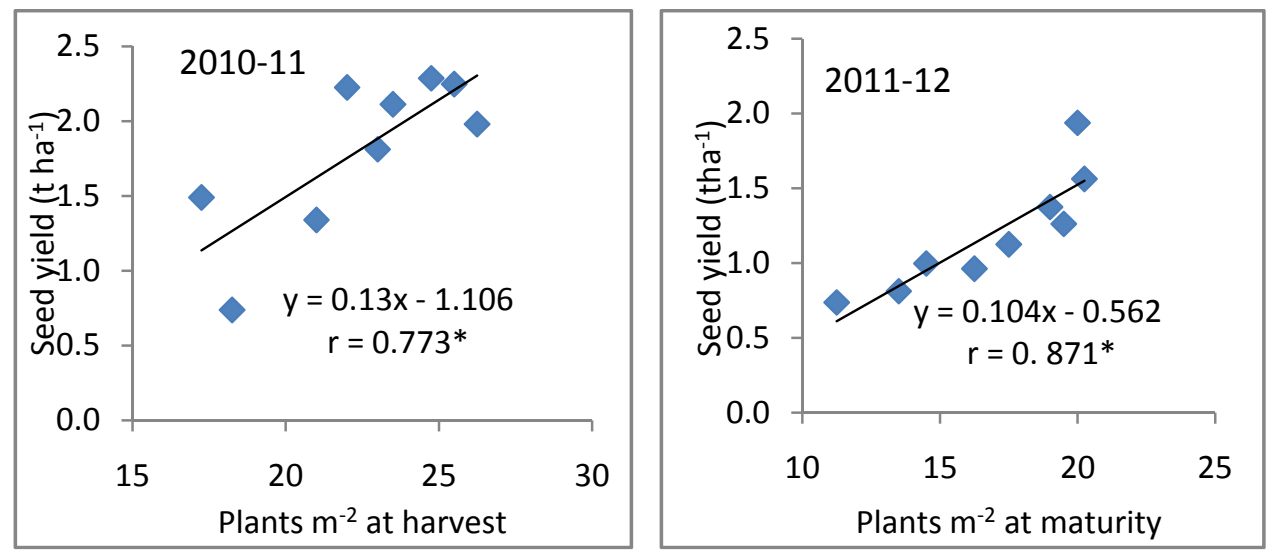

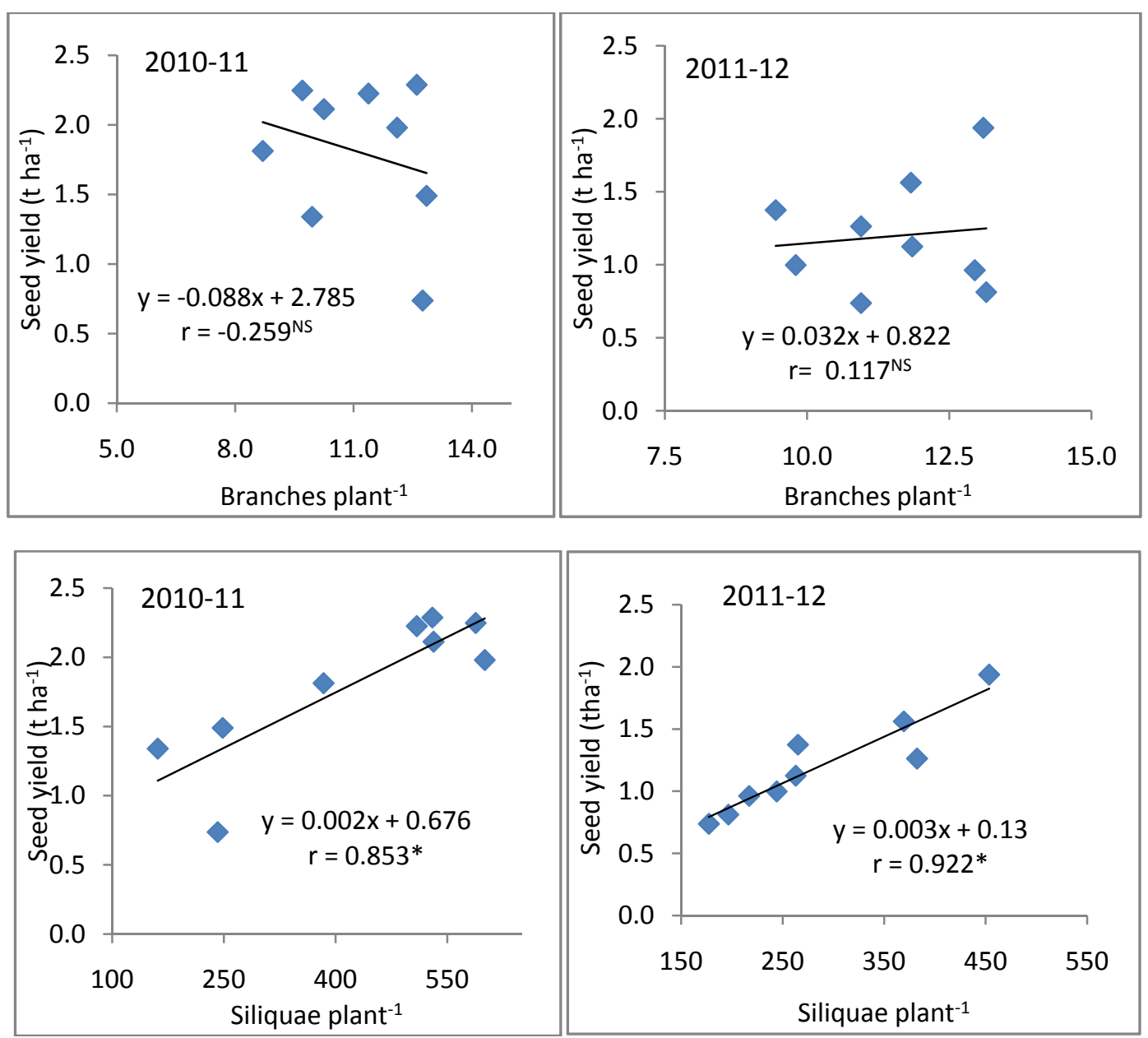

Figure 3. Regression and correlation of mustard yield (y) with major yield attributes $(x)$

residue. Application of Leucaena twigs over two years in the fixed plots increased fertility status and moisture holding capacity of the soil resulting high plant population per square metre (20.3) and 1000 seed weight $(4.92 \mathrm{~g})$. The favourable improvements in yield attributes could be attributed to the influence of previous legume crops and organic mulches as a result of greater nutrient uptake, efficient partitioning of metabolites and adequate accumulation of translocation of photosynthates. Adequate supply of moisture enhances the growth and dry matter production of crops (Tetarwal and Rana, 2006, Parihar et al., 2010). Singh et al. (2003) and Singh et al. (2008) found significant increase in yield attributes of mustard grown after cluster bean and green gram and mulched with crop residue after legume crops.

Regression analysis between yields and major yield attributes of mustard revealed significantly positive correlation between mustard yield and number of siliquae per plant, but non-significant between yield and primary branches per plant (Figure 3). 
Pooled analysis of mustard seed yield as affected by years, preceding crops and residue management is presented in Table 3. This Table shows that all production factors affect mustard yield singly as well as in combination. There was $51 \%$ higher yield (1.80 ton per hectare) in 2010/11 than in 2011/12 (1.20 ton per hectare) due to favorable weather condition.

Table 3. Pooled analysis on seed yield of mustard $\left(t \mathrm{ha}^{-1}\right)$ as affected by year, preceding crops and residue management

\begin{tabular}{|c|c|c|c|c|c|c|c|c|c|}
\hline \multirow{2}{*}{$\begin{array}{l}\text { Preceding } \\
\text { crops }\end{array}$} & \multicolumn{4}{|c|}{$2010 / 11$} & \multicolumn{4}{|c|}{$2011 / 12$} & \multirow{2}{*}{$\begin{array}{c}\text { Overall } \\
\text { mean }\end{array}$} \\
\hline & NR & CR & LR & Mean & NR & CR & LR & Mean & \\
\hline Pearl millet & 1.34 & 1.81 & 2.25 & 1.80 & 0.74 & 1.38 & 0.99 & 1.04 & 1.42 \\
\hline Cluster bean & 0.74 & 2.11 & 2.29 & 1.71 & 0.96 & 1.26 & 1.93 & 1.38 & 1.55 \\
\hline Green gram & 1.49 & 2.23 & 1.98 & 1.90 & 0.81 & 1.56 & 1.13 & 1.17 & 1.53 \\
\hline \multirow[t]{2}{*}{ Mean } & 1.19 & 2.05 & 2.17 & & 0.84 & 1.40 & 1.35 & 1.20 & \\
\hline & Year (A) & Precedin & crop (B) & Resid & (C) & $A \times B$ & $\mathrm{~A} \times \mathrm{C}$ & $\mathrm{B} \times \mathrm{C}$ & $A \times B \times C$ \\
\hline $\mathrm{SEm} \pm$ & 0.037 & & 0.046 & & 0.046 & 0.065 & 0.065 & 0.079 & 0.112 \\
\hline $\mathrm{CD}(\mathrm{P}=0.05)$ & 0.075 & & 0.093 & & 0.093 & 0.131 & 0.131 & 0.161 & 0.227 \\
\hline
\end{tabular}

There was fair distribution of rainfall throughout the mustard growing season in 2010/11, and the last rainfall $(49 \mathrm{~mm})$ received in mid-February was coincided with flowering and fruiting. The use of crop residue controlled evaporation loss and increased soil fertility through its decomposition. As a result, the yield was higher with Leucaena twigs than no residue.

\section{Economics of mustard}

Economic analysis of mustard revealed that cost of cultivation was relatively higher in 2011/12 than 2010/11 (Table 4). The increase in production cost was due to increase in labour wages from Rs 150/man day in 2010/11 to Rs 200/man day in 2011/12, and costs of other inputs. Another reason of high cost of production was due to the estimation of the value of crop residue in added market price. Although the output price was higher in 2011/12, the net return from the crop was low due to poor yield. The highest returns and net returns on investment were achieved under cluster bean with Leucaena twigs. Growing mustard after cluster bean and green gram with crop residue and Leucaena twigs helped improving profitability under zero-till semi-arid condition. These findings are in accordance with Saxena et al. (1998); Singh et al. (2003); and Singh et al. (2008). 
Table 4. Effect of crop residue and Leucaena twigs on economics of mustard after rainy season crops

\begin{tabular}{|c|c|c|c|c|c|c|c|c|}
\hline \multirow[t]{2}{*}{ Treatment } & \multicolumn{2}{|c|}{$\begin{array}{l}\text { Cost of cultivation } \\
\left(\mathrm{x} 10^{3} \mathrm{ha}^{-1}\right)\end{array}$} & \multicolumn{2}{|c|}{$\begin{array}{c}\text { Gross returns } \\
\left(\mathrm{x} 10^{3} \mathrm{ha}^{-1}\right)\end{array}$} & \multicolumn{2}{|c|}{$\begin{array}{l}\text { Net returns } \\
\left(\mathrm{x} 10^{3} \mathrm{ha}^{-1}\right)\end{array}$} & \multicolumn{2}{|c|}{$\begin{array}{c}\text { Net returns/` } \\
\text { invested }\end{array}$} \\
\hline & $2010 / 11$ & $2011 / 12$ & $2010 / 11$ & $2011 / 12$ & $2010 / 11$ & $2011 / 12$ & $2010 / 11$ & $2011 / 12$ \\
\hline $\begin{array}{l}\text { Pearl millet - no } \\
\text { residue }\end{array}$ & 10.23 & 14.26 & 26.12 & 19.91 & 15.89 & 5.65 & 1.55 & 0.40 \\
\hline $\begin{array}{l}\text { Pearl n } \\
\text { crop re } \\
\text { Pearl n }\end{array}$ & 8 & .36 & .36 & .75 & .68 & 20.40 & 1.87 & 1.18 \\
\hline $\begin{array}{l}\text { twigs } \\
\text { an - }\end{array}$ & 11.73 & 16.26 & 44.37 & 27.05 & 32.64 & 10.79 & 2.78 & 0.66 \\
\hline & 10.23 & 14.26 & 15.04 & 25.38 & 4.81 & 11.12 & 0.47 & 0.78 \\
\hline crop & 12.68 & 17.36 & 41.86 & 34.49 & 29.18 & 17.14 & 2.30 & 0.99 \\
\hline Leuc & 11.73 & 16.26 & 45.75 & 51.56 & 34.02 & 35.30 & 2.90 & 2.17 \\
\hline im - no & 10.23 & 14.26 & 29.19 & 21.34 & 18.96 & 7.08 & 1.85 & 0.50 \\
\hline $\begin{array}{l}\text { Green } \\
\text { crop r } \\
\text { Green }\end{array}$ & 12.68 & 17.36 & 44.21 & 42.21 & 31.53 & 24.85 & 2.49 & 1.43 \\
\hline Leucaena twigs & 11.73 & 16.26 & 39.27 & 30.60 & 27.54 & 14.35 & 2.35 & 0.88 \\
\hline
\end{tabular}

\section{Acknowledgements}

This work is a part of Ph D study of the first author. ICCR is thanked for providing SAARC scholarship and CIMMYT-India for research grants and field workers of Agronomy Division, IARI, Pusa, New Delhi, India for their precise works.

\section{References}

Ali, M, AN Ganeshsmurthy and Ch Srinivasarao. 2002. Role of pulses in soil health and sustainable crop production. Indian Journal of Pulse Research 15 (2). 107-117.

Dhyani, SK, R Newaj and AR Sharma. 2009. Agro-forestry. its relation with agronomy, challenges and opportunities. Indian Journal of Agronomy 54 (3). 259-266.

Faroda, AS, N L Joshi, R Singh and A Saxena. 2007. Resource management for sustainable crop production in arid zone. a review. Indian Journal of Agronomy 52 (3). 181-193.

Gomez, KA and AA Gomez. 1984. Statistical procedures for agricultural research. John Willey and Sons, NY.

Jat, ML, MK Gathala, JK Ladha, YS Saharawat, AS Jat, SK Sharma, V Kumar, and R Gupta. 2009. Evaluation of precision land levelling and double zero-till systems in the rice-wheat rotation. water use, productivity, profitability and soil physical properties. Soil and Tillage Research 105. 112-121. 
Parihar, CM, KS Rana and SR Kantwa. 2010. Nutrient management in pearl millet (Pennisetum glaucum) - mustard (Brassica juncea) cropping system as affected by land configuration under limited irrigation. Indian Journal of Agronomy 55 (3). 191-196.

Rathore, AL, AR Pal and KK Sahu. 1998. Tillage and mulching effects on water use, root growth and yield of rainfed mustard and chickpea grown after lowland rice. Journal of the Science of Food and Agriculture 78(2). 149-161.

Rathore, BS, VS Rana and RK Nanwal. 2008. Effect of plant density and fertility levels on growth and yield of pearl millet (Pennisetum glaucum) hybrids under limited irrigation conditions in semi-arid environment. Indian Journal of Agricultural Sciences 78 (1). $667-670$.

Saxena, A. 2008. Effect of mustard residues on weed population, soil moisture and cluster bean productivity. Annals of Arid Zone 47 (1). 25-32.

Saxena, A, DV Singh and NL Joshi. 1998. Effects of tillage and cropping systems on soil moisture balance and pearl millet yield. Journal Agronomy and Crop Science 178. 251-257.

Saxena, MC. 2012. Challaneges and opportunities for food legume reeararch and development. Paper presented on the $6^{\text {th }}$ M.S. Swaminathan Award Lecture at IARI, Pusa, New Delhi, January 25, 2012.

Sharma, AR, R Singh, SK Dhyani and RK Dube. 2010. Moisture conservation and nitrogen recycling through legume mulching in rainfed maize (Zea mays)-wheat (Triticum aestivum) cropping system. Nutrient Cycling in Agro-ecosystems 87(2). 187-197.

Singh, BP, MC Mundra and SC Gupta. 2003. Productivity, stability and economics of various cropping systems in semi-arid ecosystem. Crop Research (Hisar) 25(3). 472-477.

Singh, R, B Singh and M Patidar. 2008. Effect of preceding crops and nutrient management on productivity of wheat (Triticum aestivum) - based cropping system in arid region. Indian Journal of Agronomy 53 (4). 267-272.

Singh, V, SK Sharma, D Ram, RK Siag and BL Verma. 1998. Performance of different crops sequences under various irrigation levels. Indian Journal of Agronomy 35. 287-296.

Tetarwal, JP and KS Rana. 2006. Impact of cropping system, fertility level and moisture conservation practice on productivity, nutrient uptake, water use and profitability of pearl millet (Pennisetum glaucum) under rainfed conditions. Indian Journal of Agronomy 51(4). 263-266. 